\title{
Unusual Clinical Presentation of a Primary Cutaneous Follicle Center Lymphoma on the Scalp of a Middle-Aged Female: Case Report and Review of the Literature
}

\author{
Azhar A. Ahmed ${ }^{a, c}$ Hind Almohanna ${ }^{b}$ Jacob Griggs ${ }^{c}$ Antonella Tosti ${ }^{c}$ \\ ${ }^{a}$ Department of Dermatology, King Fahad General Hospital, Medina, Saudi Arabia; ${ }^{b}$ Department of Dermatology \\ and Dermatologic Surgery, Prince Sultan Military Medical City, Riyadh, Saudi Arabia; ${ }^{\circ}$ Dr. Phillip Frost Department of \\ Dermatology and Cutaneous Surgery, University of Miami Hospital, University of Miami Miller School of Medicine, \\ Miami, FL, USA
}

\section{Established Facts}

- Primary cutaneous follicle center lymphoma (PCFCL) is a type of primary cutaneous B-cell lymphoma with an indolent course and excellent prognosis.

- PCFCL classically manifest with erythematous nodules and plaques on the head, neck, or back.

\section{Novel Insights}

- The reported case presented with unusual clinical manifestation in the form of an alopecic atrophic patch following successful treatment of a large subcutaneous nodule that regressed after rituximab infusion.

\section{Keywords}

Scalp lymphoma • Non-Hodgkin's B-cell lymphoma • Alopecia · Primary cutaneous B-cell lymphoma · Primary cutaneous follicle center lymphoma

\begin{abstract}
Primary cutaneous follicle center lymphoma (PCFCL) is a rare type of indolent, low-grade cutaneous B-cell lymphoma with an excellent prognosis. It usually presents with erythematous nodules and plaques on the head, neck, or back. The diagnosis is primarily based on histopathology, immunohistochemistry, and molecular studies. We describe a case of
\end{abstract}

PCFCL causing a well-defined alopecic atrophic patch. The patch developed in the area of a large subcutaneous nodule that regressed after treatment with rituximab infusion. We hypothesize that the alopecia could have been caused by pressure.

(c) 2019 S. Karger AG, Basel

\section{KARGER}

(C) 2019 S. Karger AG, Basel

E-Mail karger@karger.com

www.karger.com/sad

\section{Introduction}

Primary cutaneous B-cell lymphomas (PCBLs) are a heterogeneous group of non-Hodgkin's B-cell lymphomas that originate in the skin and have no extracutaneous 


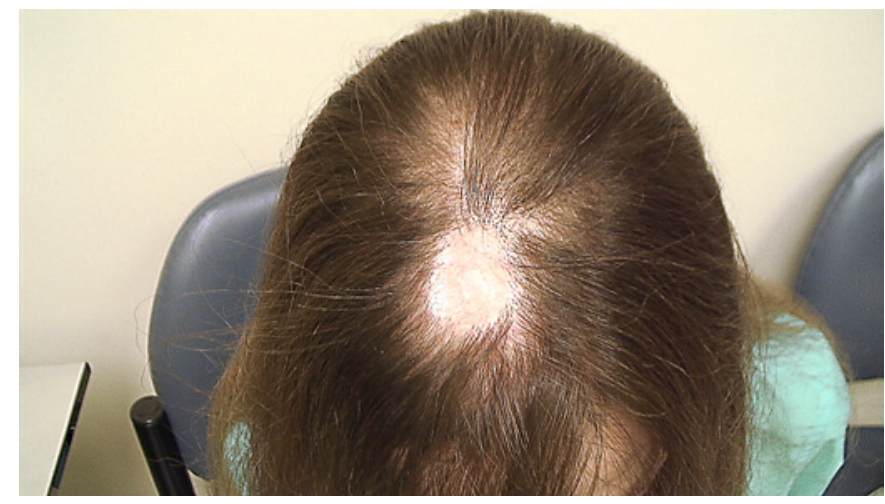

Fig. 1. Circumscribed alopecia subsequent to a subcutaneous scalp nodule.

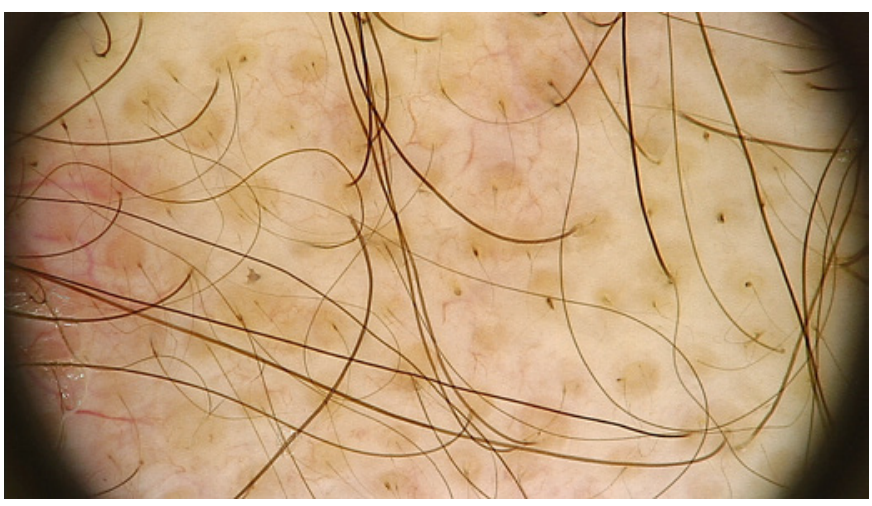

Fig. 3. Dermoscopic features on the hairless patch showing preserved follicular opening with miniaturized hair over erythematous background.

manifestations at the time of diagnosis [1]. According to the World Health Organization (WHO) and the European Organization for Research and Treatment of Cancer (EORTC) (WHO-EORTC cutaneous lymphoma classification), PCBLs are classified into 3 main types: primary cutaneous marginal zone lymphoma, primary cutaneous follicle center lymphoma (PCFCL), and primary cutaneous diffuse large B-cell lymphoma, leg type.

We report a case of PCFCL presenting with a welldefined atrophic alopecic patch following successful treatment of a large subcutaneous nodule in the same area that regressed after rituximab infusion.

\section{Case Report}

A 64-year-old female with a history of PCFCL grade 1-2 followed by hematology/oncology consulted our clinic for a well-defined $(3 \times 3 \mathrm{~cm})$ atrophic patch of hair loss on the central scalp. She

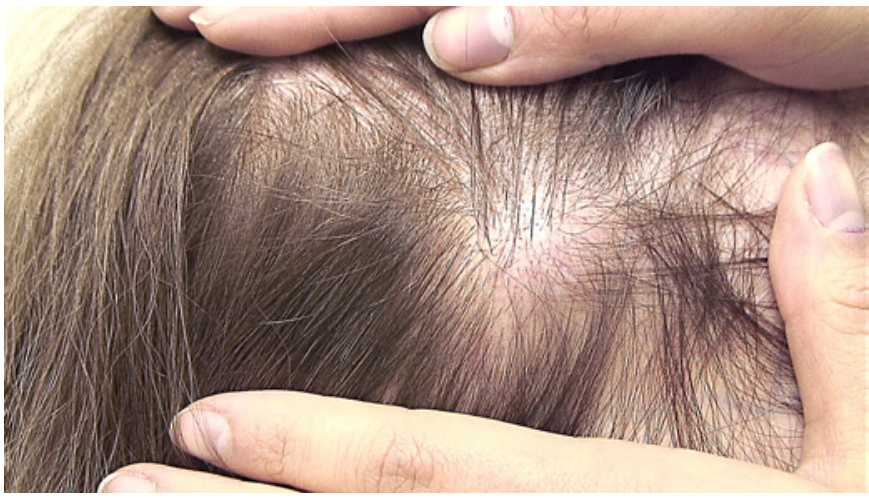

Fig. 2. Skin-colored nodule in the right temporal area.

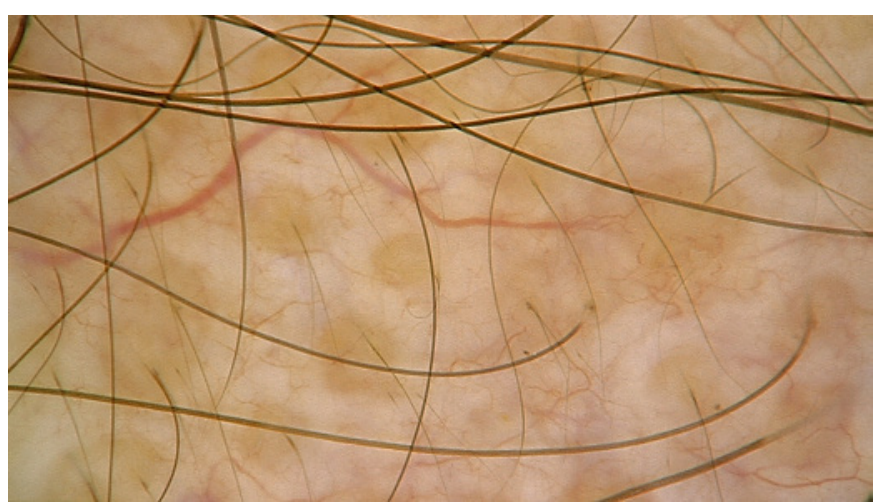

Fig. 4. Background of arborizing blood vessels in the periphery of the alopecic patch.

stated that 3 years ago she had a large subcutaneous nodule due to a lymphoma in the region of the patch, and that the nodule regressed after treatment with rituximab, leaving the alopecic area (Fig. 1). She detailed that she had many other subcutaneous nodules that regressed following treatment without causing alopecia. At the time of her visit, she also had a nonmobile $3 \times 2 \mathrm{~cm}$ subcutaneous skin-colored nodule on her right temporal area with normal-appearing hair density overlaying the mass (Fig. 2). Dermoscopy of the alopecic patch showed preserved follicular openings with vellus and miniaturized hair over an erythematous background, with red dots and arborizing blood vessels (Fig. 3, 4). Dermoscopy of the right temporal area overlying the nonalopecic nodule disclosed miniaturized hair follicles in a background of serpentine, arborizing blood vessels (Fig. 5).

She refused a biopsy from the alopecic patch.

History revealed that diagnosis of PCFCL was performed in 2016 by histopathology (Fig. 6).and immunohistochemistry. Staging included laboratory analyses, PET/CT scan, lymph node ultrasonography, bone marrow aspirate, and biopsy, all of which were negative.

She was treated with rituximab infusion $375 \mathrm{mg} / \mathrm{m}^{2}$ weekly for 4 weeks, then every 3 months, starting in June 2016. 


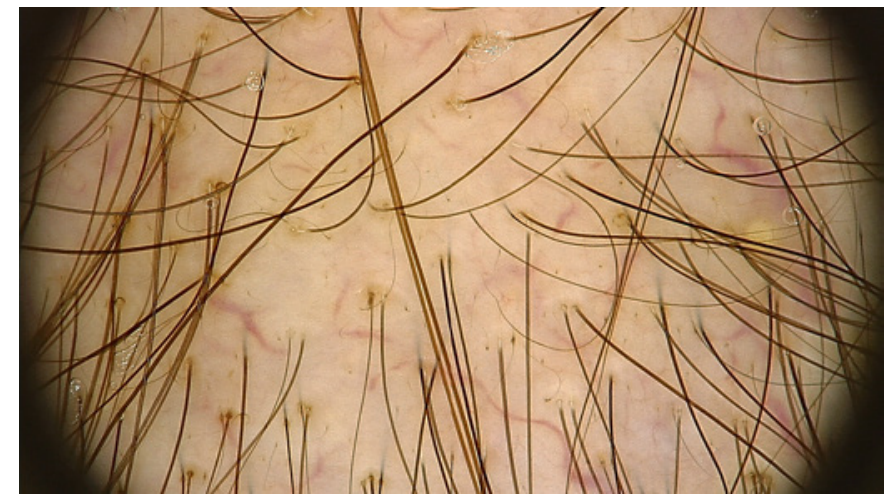

Fig. 5. Dermoscopic feature of the right temporal scalp nodule, showing miniaturized hair follicles and arborizing blood vessels in the background.

\section{Discussion}

PCFCL is a rare type of indolent, low-grade cutaneous B-cell lymphoma with a 5-year survival rate $>95 \%$ [2]. It represents $10-20 \%$ of all cutaneous lymphomas [2,3].

As a type of PCBLs, the disease has been associated with Borrelia burgdorferi infection, Helicobacter pylori, and Epstein-Barr virus as triggering factors [4].

PCFCL has a predilection for the head and neck, and scalp involvement is well known in the literature. Numerous cases of scalp PCFCL with different clinical patterns have been reported [5-9].

PCFCL classically presents with subcutaneous scalp nodule(s). Imai et al. [5] reported a 32-year-old male with dome-shaped, flesh-colored, subcutaneous nodule on the forehead (diameter $1.2 \mathrm{~cm}$ ) and parietal scalp (diameter $3.0 \mathrm{~cm}$ ), glassy in appearance. No regional or systemic lymphadenopathy was detected.

Similarly, Camargo et al. [6] presented a 45-year-old male with infiltrated plaques and erythematous hard nodules on the left parietal scalp of 1-year duration (measuring approximately $8 \times 4 \mathrm{~cm}$ ) without palpable lymphadenopathy.

PCFCL can present with scalp telangiectasia. IngenHousz-Oro et al. [7] presented a 65-year-old man with extensive scalp telangiectasias surrounding a $1-\mathrm{cm}$ subcutaneous nodule of the forehead. The diagnosis of PCFCL was made based on histopathology and immunohistochemistry.

Another clinical pattern of scalp PCFCL documented in the literature is scalp alopecia. de Masson et al. [8] retrospectively analyzed 150 cases of PCFCL identified in their local cutaneous lymphoma database from 2009 to

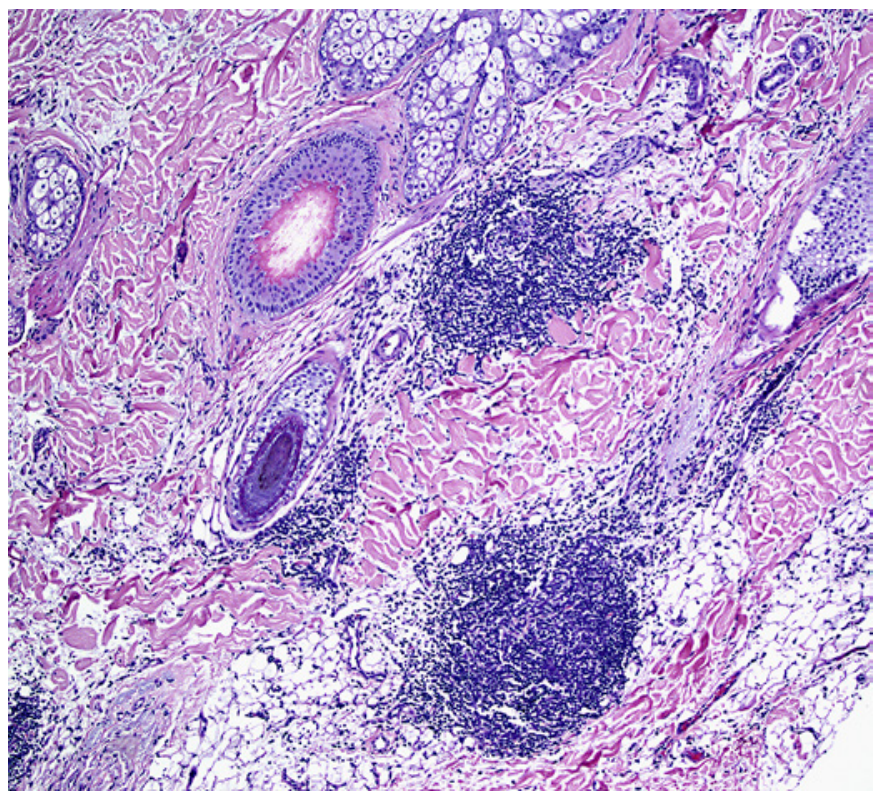

Fig. 6. Histopathology of a nodule showing dense atypical lymphoid infiltrates.

2017. Fourteen patients presented with alopecic patches of the scalp. The study group included 11 males and $3 \mathrm{fe}-$ males with a median age of 56 years. The scalp lesions were isolated findings in all but 1 case with extension to the forehead. There was a single patch in 10 cases and multiple lesions in 4 patients. Seven patients had telangiectasia [8].

Seven patients in the study by Massone et al. [9] presented clinically with diffuse, ill-defined, partly erythematous, partly hypopigmented scalp macules with a subtle area of scarring alopecia on their vertex. Papules, plaques, and nodules were not observed in any patient.

Kluk et al. [10] portrayed a 55-year-old woman with a 5 -year history of scalp hair thinning associated with redness, soreness, and pruritus. Examination showed marked scarring alopecia over the vertex and frontal scalp. Histopathology and immunohistochemistry were consistent with PCFCL; miniaturizing hair follicles support the diagnosis of coexistent androgenetic alopecia.

One case of PCFCL presenting simultaneously with alopecia areata has been described. Pink papules on the left temporal scalp progressed over a course of 6 months to form pink nodules of the glabellar region, zygoma, and cheeks. The patient had patches of hair loss in the beard and on the scalp. On examination, there were multiple pink to violaceous papules with glossy surface on the forehead and glabella, as well as 2 subcutaneous nodules on 
Table 1. Histopathologic differential diagnosis of a primary cutaneous follicle center lymphoma

\begin{tabular}{|c|c|c|c|c|}
\hline & $\begin{array}{l}\text { Primary cutaneous } \\
\text { follicle center } \\
\text { lymphoma (PCFCL) }\end{array}$ & $\begin{array}{l}\text { Follicular } \\
\text { lymphoma (FL) }\end{array}$ & $\begin{array}{l}\text { Reactive } \\
\text { lymphoid } \\
\text { hyperplasia } \\
\text { (RLH) }\end{array}$ & $\begin{array}{l}\text { Primary cutaneous } \\
\text { diffuse large B-cell } \\
\text { lymphoma (PCLBCL) }\end{array}$ \\
\hline $\begin{array}{l}\text { Clinical } \\
\text { presentation }\end{array}$ & $\begin{array}{l}\text { Slowly growing } \\
\text { solitary or localized } \\
\text { lesions on the scalp } \\
\text { or trunk of a } \\
\text { middle-aged man } \\
\text { [8] }\end{array}$ & $\begin{array}{l}\text { Fever, night } \\
\text { sweating (B } \\
\text { symptoms), } \\
\text { painless } \\
\text { lymphadenopathy } \\
{[2]}\end{array}$ & $\begin{array}{l}\text { Acneiform or bite } \\
\text { on the head, neck } \\
\text { or trunk with } \\
\text { spontaneous } \\
\text { resolution [2] }\end{array}$ & $\begin{array}{l}\text { Rapidly growing leg } \\
\text { nodule(s) [12] } \\
\text { Transformation of } \\
\text { PCFCL to PCLBCL } \\
{[12]}\end{array}$ \\
\hline Histopathology & $\begin{array}{l}\text { Centrocytes and } \\
\text { centroblasts with } \\
\text { prominent stromal } \\
\text { component [24] }\end{array}$ & $\begin{array}{l}\text { Follicular } \\
\text { structures with } \\
\text { centrocytes and } \\
\text { centroblasts [25] }\end{array}$ & $\begin{array}{l}\text { Regular follicles } \\
\text { with centrocytes } \\
\text { and centroblasts } \\
\text { with polarized } \\
\text { mantle zone [25] }\end{array}$ & $\begin{array}{l}\text { Large cell centroblasts } \\
\text { and immunoblasts } \\
\text { with no centrocytes [2] }\end{array}$ \\
\hline $\begin{array}{l}\text { Immunohisto- } \\
\text { chemistry genetic } \\
\text { study }\end{array}$ & $\begin{array}{l}\text { CD20+, BCL-2-, } \\
\text { CD10 } 1 \text { BCL-6+, } \\
\text { IRF4/MUM1-, } \\
\text { immunoglobulin } \\
\text { expression usually } \\
\text { negative } \\
\text { Ki-67 proliferation } \\
\text { index is low, maybe } \\
\text { high but not } \\
\text { polarized [9] }\end{array}$ & $\begin{array}{l}\text { CD10+, BCL-2+, } \\
\text { BCL- } 6+; 85 \% \\
\text { have } t(14 ; 18), \\
\text { 1p36 deletion [2] }\end{array}$ & $\begin{array}{l}\text { Ki- } 67 \text { high } \\
\text { and polarized } \\
\text { in follicles [2] }\end{array}$ & $\begin{array}{l}\text { BCL-2+, CD10 } \pm \text {, } \\
\text { BCL-6 } \pm \text {, C-MYC } \pm \text { [2] } \\
\text { FOXP1+, IRF4/ } \\
\text { MUM1 } \pm \text { expressed } \\
\text { in IgM }[2,12]\end{array}$ \\
\hline
\end{tabular}

the right cheek. Alopecic patches were well circumscribed and oval in the beard and on the scalp, with white hair regrowth [11].

PCFCL can rarely transform to diffuse large B-cell lymphoma. Colovic et al. [12] reported a 44-year-old male with PCFCL on the scalp and a 16-year history of occipital and parietal alopecia and scalp itching. Recently, small violaceous scalp nodules with skin crusting and thickening appeared with a serosal exudate but without regional lymphadenopathy. A biopsy was taken and confirmed the diagnosis of PCFCL, with aggressive transformation to diffuse large B-cell lymphoma [12].

Common dermoscopic findings in PCFCL or any primary cutaneous B-cell lymphoma are nonspecific and can also be seen on other scalp tumors or inflammations, but it may direct the physicians to reconsider their diagnosis. Dermoscopic features reported in PCBLs include arborizing (serpentine) [13] blood vessels over a salmon-colored background and white areas/circles [14]. The increased vascularity seen in PCBLs is due to the angiogenesis that accompanies the neoplastic process [15].
Histopathological findings in PCBL show irregular, overlapping nodules, recapitulating follicles, or diffuse sheets of medium-sized B cells with a germinal center phenotype. Tumors involve the dermis and subcutaneous tissue but are separated from the epidermis by the grenz zone [16]. The neoplastic follicles show several features that distinguish them from reactive follicles. These features include abnormal irregular follicles, an underdeveloped or absent mantle zone [17], absence of tingible body macrophages [16], and extension of neoplastic cells beyond the follicular dendritic cell network that does not show the polarized light and dark zones. Neoplastic cells are centrocytes (small and large cleaved follicle center cells) and variable numbers of centroblasts (large noncleaved follicle center cells with prominent nucleoli) $[16,18,19]$.

The usual immunophenotype of neoplastic cells will show B-cell markers, including CD19+, CD20+, CD22+, $\mathrm{CD} 79 \mathrm{a}+$, and PAX5+, and positivity to at least one follicle center marker, which is usually BCL-6 or, less commonly, CD10 [16]. Additionally, BCL-6+ cells may extend beyond the follicular meshwork, which helps to exclude reactive lymphoid hyperplasia [20]. Expression of BCL-2 protein in 
PCFCL is usually absent but can be present in a minority of follicular B cells similar to the case presented [9,21]. Ki67 expression determines the proliferative nature of the disease and is commonly used to distinguish between follicular reactive hyperplasia and follicular malignancies [22]. There is negative staining for MUM1, FOP1, p63, and immunoglobulin $\mathrm{M}$, which helps to differentiate it from primary cutaneous diffuse large B-cell lymphoma [23].

PCFCL should be differentiated from other similar histopathologic diagnoses like systemic/nodal follicular lymphoma with secondary skin involvement, reactive lymphoid hyperplasia, and primary cutaneous diffuse large B-cell lymphoma (Table 1).

Any new patient presenting with scalp lymphoma should be screened for systemic involvement. National Comprehensive Cancer Network (NCCN) guidelines include physical examination, a complete blood cell count with differential, a comprehensive metabolic panel, lactate dehydrogenase (LDH), and PET/CT scans of the chest/ abdomen/pelvis with contrast enhancement $[16,26]$.

PCFCL on the scalp has an excellent prognosis as PCFCL on any other body location. With treatment, $99 \%$ of patients enter complete remission. Local recurrence can occur in $20-30 \%$ of cases [27], and extracutaneous involvement is uncommon [16]. Of note, cutaneous relapse does not mean disease progression [28]. The prognosis does not correlate with the histological pattern or with multifocal clinical presentation [28]. Transformation to diffuse large B-cell lymphoma may occur and should be considered in treatment-resistant cases [29]. The presence of BCL- 2 or BCL- 6 gene rearrangements or loss of 1 p36 in PCFCL also does not affect prognosis [2].

Treatment of PCFCL is important because untreated lesions may enlarge and become locally aggressive. Treatment includes local radiotherapy [9], excision [30], systemic rituximab [31], intralesional rituximab [31], intralesional interferon- $\alpha$ [32], intralesional steroids [16], and combination chemotherapy [22].

Local radiotherapy has an excellent outcome, reaching in up to $90 \%$ of cases a complete response [33], but it may lead to scarring alopecia on the scalp as a side effect $[5,10]$. Akhtari et al. [34] suggested that lower doses of radiation can successfully eradicate the tumor (4-12 Gy in a few fractions vs. the traditional 24- to 36-Gy treatment for several weeks).

Surgical excision may be reasonable for small, welldemarcated, solitary lesions. Necessary safety margins are unknown [17]. The lesion may locally recur in up to $33 \%$ of cases [30, 35].

Systemic rituximab, a recombinant, chimeric antiCD20 antibody, has also been used successfully (375 mg/

Primary Cutaneous Follicle Center

Lymphoma on a Female Scalp $\mathrm{m}^{2}$ weekly for 1-8 weeks) [10]. Systemic rituximab is commonly used in patients with extensive scalp involvement who cannot tolerate surgical resection [36]. Rituximab is safer and more tolerable than other chemotherapy drugs [37]. With intravenous infusion of rituximab, the remission rate is $77 \%$, and the recurrence rate is about $20 \%$ [31].

Intralesional rituximab for scalp alopecic may have promising results. Therapy is effective via the intralesional route in about $89 \%$, and the recurrence rate is about $40 \%$ [31]. Although the recurrence rate is high, the intralesional route of rituximab is more convenient and has less side effects [31] especially if we consider it as alternative to local radiotherapy, which may increase the risk of scalp scarring alopecia [38].

Topical therapies such as high potency steroids, 5\% imiquimod [11], nitrogen mustard, bexarotene, and intralesional steroids have been tried with some success in selected patients [39].

Richmond et al. [11] treated a patient with both scalp PCFCL and alopecia areata with topical imiquimod and systemic steroids. The patient showed regression of both diseases, which may suggest a relationship between Band $\mathrm{T}$-cell populations triggering these lesions.

Intralesional injections with interferon- $\alpha$ have been tried with a remission rate of about $72.3 \%$ but also with a high recurrence rate reaching about 90\% [32].

Systemic multiagent chemotherapy (rituximab, cyclophosphamide, doxorubicin, vincristine, and prednisolone [R-CHOP], or rituximab, cyclophosphamide, vincristine, and prednisolone) with or without local radiation therapy should be considered with extensive disease, extracutaneous involvement, or lesions on the legs $[22,36]$.

de Masson et al. [8] retrospectively analyzed 14 patients with scalp PCFCL. One of them had spontaneous regression of the lesion. One patient received intralesional injections of triamcinolone without success and was then treated with rituximab infusion with complete remission. One patient received combination chemotherapy (intravenous rituximab, cyclophosphamide, vincristine, and prednisolone) with complete remission. Two patients relapsed after treatment with rituximab, 3 patients after radiation therapy, and 1 patient after topical steroids.

\section{Conclusion}

PCFCL is a rare disease with an excellent prognosis. We must distinguish it from other overlapping lymphomas such as systemic follicle lymphoma by histopathological sectioning and immunohistochemistry.

Skin Appendage Disord 2019;5:379-385 383 
With regard to the case presented, we were able to find in the literature another case of PCFCL presenting with scarring alopecia, where the lesion was biopsied and showed PCFCL in a background of androgenetic alopecia. In our patient, however, the alopecia was nonscarring, which could have been caused by pressure from the lesion, although it remains to be determined why it only developed in one of the nodular lesions.

\section{Acknowledgments}

Special thanks go to the staff of the clinics at the University of Miami Hospital for their help and support.

\section{Statement of Ethics}

All procedures followed were in accordance with the ethical standards of the responsible committee on human experimentation (institutional and national) and with the Helsinki Declaration of 1964, as revised in 2013. The patient has given her written informed consent to publish the case (including the publication of the images).

\section{Disclosure Statement}

Dr. Antonella Tosti: Consultant P\&G, DS Laboratories, Monat, PI: Incyte, Pfizer, Aclaris, Nutrifol.

All other authors have nothing to disclose.

\section{Funding Sources}

No funding or sponsorship was received for this study or publication of this article.

\section{Author Contributions}

All named authors meet the International Committee of Medical Journal Editors (ICMJE) criteria for authorship for this article, take responsibility for the integrity of the work as a whole, and have given their approval for this version to be published.

\section{References}

1 Wobser M. Treatment of indolent cutaneous B-cell lymphoma. Hautarzt. 2017 Sep;68(9): 721-6. German.

2 Skala SL, Hristov B, Hristov AC. Primary Cutaneous Follicle Center Lymphoma. Arch Pathol Lab Med. 2018 Nov;142(11):1313-21.

3 Goodlad JR, Krajewski AS, Batstone PJ, McKay P, White JM, Benton EC, et al.; Scotland and Newcastle Lymphoma Group. Primary cutaneous follicular lymphoma: a clinicopathologic and molecular study of 16 cases in support of a distinct entity. Am J Surg Pathol. 2002 Jun;26(6):733-41.

4 Chian NYZ, Uddin A, Abdullah A, Thompson D, Abdullah P, Velangi S. Primary cutaneous diffuse large $\mathrm{B}$-cell lymphoma, leg type: Two Bcl-2 negative cases. J Am Acad Dermatol. 2013;68(4):AB148.

5 Imai $\mathrm{Y}$, Isoda K, Ito E, Hakamada A, Yamanishi K, Mizutani H. Primary cutaneous follicle center cell lymphoma of the scalp successfully treated with anti CD20 monoclonal antibody and $\mathrm{CHOP}$ combination therapy with no subsequent permanent loss of hair. J Dermatol. 2003 Sep;30(9):683-8.

6 Camargo CM, Bomm L, Abraham LS, Daher R, Scotelaro MF, Abulafia LA. Primary cutaneous centrofollicular lymphoma with a good response to radiotherapy. An Bras Dermatol. 2013 Nov-Dec;88(6 Suppl 1):136-8.

7 Ingen-Housz-Oro S, Jones M, Ortonne N, Haioun C, Chosidow O. Extensive telangiec- tases of the scalp: atypical presentation of primary cutaneous follicle centre lymphoma. $\mathrm{Br}$ J Haematol. 2012 Aug;158(3):297.

8 de Masson A, Bouaziz J-D, Ram-Wolff C, et al. Alopecic patches of the scalp: a variant of primary cutaneous follicle center B-cell lymphoma reported in a series of 14 cases. J Eur Acad Dermatol Venereol. 2019 May; 33(5):e209-e211.

9 Massone C, Fink-Puches R, Cerroni L. Atypical clinical presentation of primary and secondary cutaneous follicle center lymphoma (FCL) on the head characterized by macular lesions. J Am Acad Dermatol. 2016 Nov;75(5):1000-6.

10 Kluk J, Charles-Holmes R, Carr RA. Primary cutaneous follicle centre cell lymphoma of the scalp presenting with scarring alopecia. Br J Dermatol. 2011 Jul;165(1):205-7.

11 Richmond HM, Lozano A, Jones D, Duvic M. Primary cutaneous follicle center lymphoma associated with alopecia areata. Clin Lymphoma Myeloma. 2008 Apr;8(2):121-4.

12 Colovic N, Jurisic V, Terzic T, Atkinson HD, Colovic M. Immunochemotherapy for Bcl-2 and MUM-negative aggressive primary cutaneous B-cell non-Hodgkin's lymphoma. Arch Dermatol Res. 2009 Oct;301(9):689-92.

13 Geller S, Marghoob AA, Scope A, Braun RP, Myskowski PL. Dermoscopy and the diagnosis of primary cutaneous B-cell lymphoma. J Eur Acad Dermatol Venereol. 2018 Jan;32(1): 53-6.
14 Piccolo V, Mascolo M, Russo T, Staibano S, Argenziano G. Dermoscopy of primary cutaneous B-cell lymphoma (PCBCL). J Am Acad Dermatol. 2016 Oct;75(4):e137-9.

15 Schaerer L, Schmid MH, Mueller B, Dummer RG, Burg G, Kempf W. Angiogenesis in cutaneous lymphoproliferative disorders: $\mathrm{mi}-$ crovessel density discriminates between cutaneous B-cell lymphomas and B-cell pseudolymphomas. Am J Dermatopathol. 2000 Apr; 22(2):140-3.

16 Goyal A, LeBlanc RE, Carter JB. Cutaneous B-Cell Lymphoma. Hematol Oncol Clin North Am. 2019 Feb;33(1):149-61.

17 Selva R, Violetti SA, Delfino C, Grandi V, Cicchelli S, Tomasini C, et al. A Literature Revision in Primary Cutaneous B-cell Lymphoma. Indian J Dermatol. 2017 Mar-Apr;62(2):14657.

18 Swerdlow SH, Campo E, Pileri SA, Harris NL, Stein H, Siebert R, et al. The 2016 revision of the World Health Organization classification of lymphoid neoplasms. Blood. 2016 May; 127(20):2375-90.

19 Willemze R, Jaffe ES, Burg G, Cerroni L, Berti E, Swerdlow SH, et al. WHO-EORTC classification for cutaneous lymphomas. Blood. 2005 May;105(10):3768-85.

20 Milette F. Review: Skin Lymphoma. The Illustrated Guide, 4th ed., by Lorenzo Cerroni. Dermatol Pract Concept. 2014;4(4): 17. 
21 Servitje O, Climent F, Colomo L, Ruiz N, García-Herrera A, Gallardo F, et al. Primary cutaneous vs secondary cutaneous follicular lymphomas: A comparative study focused on BCL2, CD10, and $t(14 ; 18)$ expression. J Cutan Pathol. 2019 Mar;46(3):182-9.

22 Senff NJ, Noordijk EM, Kim YH, Bagot M, Berti E, Cerroni L, et al.; European Organization for Research and Treatment of Cancer; International Society for Cutaneous Lymphoma. European Organization for Research and Treatment of Cancer and International Society for Cutaneous Lymphoma consensus recommendations for the management of cutaneous B-cell lymphomas. Blood. 2008 Sep; 112(5):1600-9.

23 Giza A, Stramek T, Jaworek A, Dyduch G, Jurczak W, Skotnicki A. Scalp skin primary cutaneous follicle center lymphoma - Case report. Our Dermatol Online. 2016;7(Suppl 1):3668.

24 Soon CW, Pincus LB, Ai WZ, McCalmont TH. Acneiform presentation of primary cutaneous follicle center lymphoma. J Am Acad Dermatol. 2011 Oct;65(4):887-9.

25 Slack GW. The Pathology of Reactive Lymphadenopathies: A Discussion of Common Reactive Patterns and Their Malignant Mimics. Arch Pathol Lab Med. 2016 Sep;140(9):881-92.

26 Zelenetz AD. Guidelines for NHL: updates to the management of diffuse large B-cell lymphoma and new guidelines for primary cutaneous CD30+ T-cell lymphoproliferative disorders and $\mathrm{T}$-cell large granular lymphocytic leukemia. J Natl Compr Canc Netw. 2014 May;12(5 Suppl):797-800.
27 Abdul-Wahab A, Tang SY, Robson A, Morris S, Agar N, Wain EM, et al. Chromosomal anomalies in primary cutaneous follicle center cell lymphoma do not portend a poor prognosis. J Am Acad Dermatol. 2014 Jun; 70(6):1010-20.

28 Senff NJ, Hoefnagel JJ, Jansen PM, Vermeer $\mathrm{MH}$, van Baarlen J, Blokx WA, et al. Reclassification of 300 primary cutaneous B-Cell lymphomas according to the new WHOEORTC classification for cutaneous lymphomas: comparison with previous classifications and identification of prognostic markers. J Clin Oncol. 2007 Apr;25(12):1581-7.

29 Swerdlow SH, Quintanilla-Martinez L, Willemze R, Kinney MC. Cutaneous B-cell lymphoproliferative disorders: report of the 2011 Society for Hematopathology/European Association for Haematopathology workshop. Am J Clin Pathol. 2013 Apr;139(4):515-35.

30 Hamilton SN, Wai ES, Tan K, Alexander C, Gascoyne RD, Connors JM. Treatment and outcomes in patients with primary cutaneous B-cell lymphoma: the BC Cancer Agency experience. Int J Radiat Oncol Biol Phys. 2013 Nov;87(4):719-25.

31 Qiao J, Lu RN, Wang L, Song MY, Wang Z, Zhang $\mathrm{ZH}$, et al. [Primary cutaneous follicle center cell lymphoma: a case report and literatures review]. Zhonghua Xue Ye Xue Za Zhi. 2018 Apr;39(4):328-30.

32 Vandersee S, Terhorst D, Humme D, Beyer $\mathrm{M}$. Treatment of indolent primary cutaneous B-cell lymphomas with subcutaneous interferon-alfa. J Am Acad Dermatol. 2014 Apr; 70(4):709-15.
33 Goyal A, Carter JB, Pashtan I, Gallotto S, Wang I, Isom S, et al. Very low-dose versus standard dose radiation therapy for indolent primary cutaneous B-cell lymphomas: A retrospective study. J Am Acad Dermatol. 2018 Feb;78(2):408-10.

34 Akhtari M, Reddy JP, Pinnix CC, Allen PK, Osborne EM, Gunther JR, et al. Primary cutaneous B-cell lymphoma (non-leg type) has excellent outcomes even after very low dose radiation as single-modality therapy. Leuk Lymphoma. 2016;57(1):34-8.

35 Jacob LA, Asati V, Lakshmaiah KC, Govind BK, Lokanatha D, Babu SM, et al. Primary cutaneous B-cell lymphoma: A single-center 5-year experience. Indian J Cancer. 2018 AprJun;55(2):134-7.

36 Wilcox RA. Cutaneous B-cell lymphomas: 2016 update on diagnosis, risk-stratification, and management. Am J Hematol. 2016 Oct; 91(10):1052-5.

37 Fernández-Guarino M, Ortiz-Romero PL, Fernández-Misa R, Montalbán C. Rituximab en el tratamiento de los linfomas cutáneos B primarios: revisión. Actas Dermosifiliogr. 2014;105(5):438-45.

38 Kerl K, Prins C, Saurat JH, French LE. Intralesional and intravenous treatment of cutaneous B-cell lymphomas with the monoclonal anti-CD20 antibody rituximab: report and follow-up of eight cases. Br J Dermatol. 2006 Dec;155(6):1197-200.

39 Perry A, Vincent BJ, Parker SRS. Intralesional corticosteroid therapy for primary cutaneous B-cell lymphoma. Br J Dermatol. 2010 Jul; 163(1):223-5 